\author{
Блаж Андољшек (Словенија) \\ Одделение за етнологија и културна антропологија \\ Филозофски факултет \\ Универзитет во Љубљана \\ е-пошта: bandoljsek@gmail.com
}

\title{
ЗЕМЈАТА СЕ ТРЕСЕШЕ ЦЕЛА НОЌ \\ СЕК̈АВАњА И ПРИКАЗНИ НА СКОПЈАНИ ЗА КАТАСТРОФАЛНИОТ ЗЕМЈОТРЕС ВО 1963 ГОДИНА
}

\begin{abstract}
Апстракт: На 26 јули 1963 година се случи силен земјотрес, кој уништи околу 80 проценти од градот. Повеќе од 1070 луѓe ги загубија животите. Сеќавањата на луѓето што го преживеаја земјотресот сѐ үште се многу живи. И покрај огромната штета што ја направи земјотресот, тој исто така ја поттикна солидарноста на светот. Донации и помош пристигнувале од многу држави. Во текстот ќе се фокусирам на животните приказни и сеќавања за периодот пред, за време и по земјотресот. Денеска сѐ үште постојат потсетници што посочуваат на тешкиот период, како што е застанатиот часовник на старата железничка станица.
\end{abstract}

Клучни зборови: антропологија на катастрофите, животни приказни, земјотрес.

\section{Вовед}

Текстот се базира на литература и интервјуа што ги направив за време на мојот престој во рамките на студентската размена од програмата Еразмүс на Универзитетот „Св. Кирил и Методиј“, на Институтот за етнологија и антропологија во Скопје. Мојот прв престој траеше пет месеци во 2018 година, а вториот се случи една година подоцна, во 2019 година. Планирав да се вратам на неколку месеци во 2020 година, но започна пандемијата со КОВИД 19, па не успеав да ги остварам сите цели во врска со теренското истражување. Сепак, во периодот кога живеев во Скопје, разговарав со многу луѓе што го преживеале големиот земјотрес од 1963 година.

Мојот прв контакт со темата беше пролетта 2018 година додека пиев кафе кај мојот пријател. Ја запознав неговата баба со која разговарав за нејзиниот живот и за историјата на Македонија, кога таа го спомна земјотресот. Тоа веднаш го привлече моето внимание и така го започнав моето истражување. Другите соговорници ги наоѓ⿱㇒㠯 најчесто на фејсбук-групата „Стари скопјани“ и со голема помош на Urban 
Living Lab - SkULL, за што сакам да изразам благодарност до Лидија Кекеновска Павиќ и до Институтот за етнологија и антропологија каде што секогаш наоѓaв помош и насоки за мојата магистерска теза.

\section{Македонија како „земјотресно подрачје“}

Земјотресите се едни од „најстрашните и најфасцинантните природни феномени што се случуваат на Земјата (...). Тие се доволно моќни за да уништат цивилизации и да ги претворат градовите во места на духови“ (Timovska 2011: 2). Земјотресите се „резултат на моменталното ослободување на енергија во Земјината кора што создава сеизмички бранови“ (Timovska 2011: 3). Македонија е лоцирана „во Медитеранскиот Сеизмички Појас (...) и, како што наведуваат многу автори (е.g. Montessus de Ballore, Sieberg, Gutenber, Richter, итн.), таа се наоѓа во зона со висока сеизмичка активност“" (Petrovski 2004: 1). Дури и во минатото, подрачјето на Вардар се сметало како „регион каде што често се случуваат земјотреси“ (Petrovski 2004: 2). Сепак, „постои некомплетна документација за овој феномен сѐ до 1905 година кога бил формиран Сеизмичкиот институт во Белград“" (Petrovski 2004: 1-2). Bo 1950 година била објавена „првата сеизмолошка мапа на Јүгославија“, која го вклүчува „интензитетот на проучуваните земјотреси во периодот од 360 година од н. е. до 1950 година“ (Petrovski 2004: 2). Мапата била „користена како мапа за сеизмичко зонирање на Југославија со Привремен законик за асеизмички дизајн на згради од 1964 година (...) по лекцијата од скопскиот земјотрес во 1963 година“ (Petrovski 2004: 2).

Земјотресот од 1963 година не бил првиот разорен земјотрес во Скопје. Реонот на Скупи во 518 година бил комплетно уништен од земјотрес. Потоа градот бил повторно изграден, но уште една катастрофа се случила во 1555 година. Градот бил повторно уништен (Јаневски 1970: 247).

Третиот земјотрес се случил на 26 јули 1963 година во 5 часот и 17 минути додека најголемиот дел од жителите спиеле. Земјотресот траел 10 секунди, и имало многу афтершокови. Земјотресот „уништил 16000 домови и оштетил үште 30 000, усмртил 1070 луѓе, а үште 3300 биле повредени и околу 200000 останале без своите домови“" (Kritikos 2019: 12). Околу 80 проценти од градот биле уништени (Sinadinovski, McCue 2013: 1). Во тој период во Скопје имало 8102 станови (Јовановски 2014: 2). Земјотресот бил плиток со магнитуда $M=6,1$ по Рихтеровата скала „со интензитет од IX (Меркалиева скала). (...) Материјалната штета била проценета на околу билион американски долари“ (Sinadinovski, McCue 2013: 3). Поголемиот дел од Република Македонија со околу 25700 км² „беше потресен со интензитет меѓу V и IX степен според Меркалиевата скала“ (Sinadinovski, McCue 2013: 3).

Луѓето со кои разговарав главно зборуваа за тоа како земјотресот ги обележал нивните животи, па може да се каже дека тие ми ги раскажуваа своите животни приказни. Животната приказна „едноставно подразбира приказна на личноста за сопствениот живот или за она за кое личноста смета дека е значајно за нејзиниот живот. Според тоа, станува збор за лична нарација, приказна за личното 
искуство, и како што произлегува од разговорот, нејзиниот онтолошки статус е изговорениот збор“ (Titon 1980: 276). Земјотресот е катастрофа што „е настан, а катастрофата е јазик. Според надворешните ефекти, некои катастрофи се кратки и акутни, додека други се долготрајни и хронични“ (Stein 2002: 157). Антропологот Стејн вели дека, кога слушаме приказни за катастрофи, тоа значи дека треба „да ги слушаме луѓето на кои се обидуваме да им помогнеме повеќе отколку што ги слушаме нашите теории и методи“ (Stein 2002: 159). Треба да се запрашаме себеси како е да се биде во нивна кожа (Stein 2002: 159). Регина Бендикс вели дека „личните нарации се (...) основниот начин што му е на располагање на поединецот за тој да може да направи ред од хаосот“ (Bendix 1990: 333). Приказните за земјотресите „со голема јасност ја покажуваат врската помеѓ настанот, личното искуство и структурирањето на ова искуство на значаен начин“ (Bendix 1990: 333). Моите соговорници повеќе или помалку ги следеа истите секвенци: пред, за време и по земјотресот. Интервјуата беа полуструктурирани, така што соговорниците главно зборуваа самите, по свој избор. Би сакал да претставам дел од нивните приказни следејќи ги споменатите секвенци.

\section{Пред земјотресот}

Господин Бранислав се сеќава на вечерта пред земјотресот:

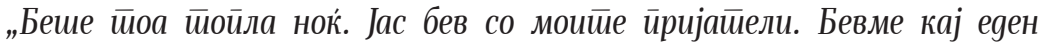
йријайел, иииевме и слушавме музика на грамофон. Сӣиев кај негіо. Неговойо семејсииво веке сиичеше, беше околу 2 часой науйро кога засйав и јас. Се разбуяив во болница. Кога се случи земјойресой,

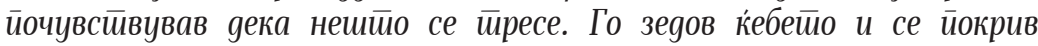

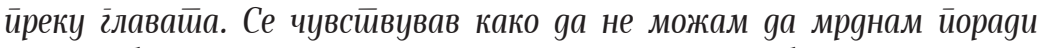

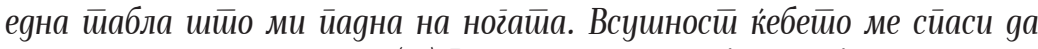

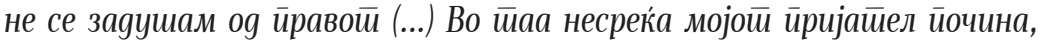

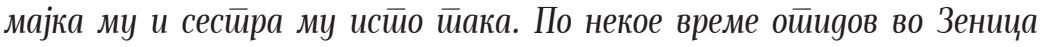
на рехабилийација. По gва месеци се случи ушиее еgен земјойрес во Сараево. Сеgев на балконой ког̈а ӣочне gа йресе. Бев исйлашен.“

Господин Сотир бил буден рано утрото и се подготвувал да оди на работа.

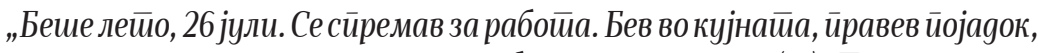
и одеgнаш сѐ йочна gа се йресе и беше мног̈у силно (...). Пойоа имаше

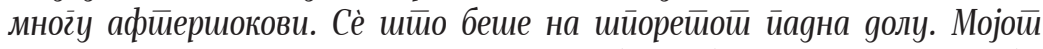

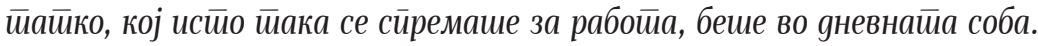

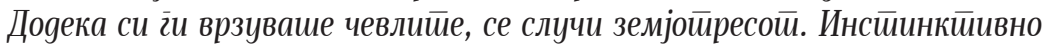

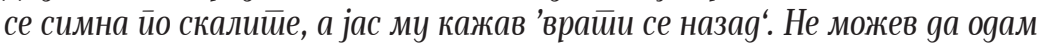
во gневнайа соба. Таму имаше раgио и кауч, а раgиойо йаgна меѓу

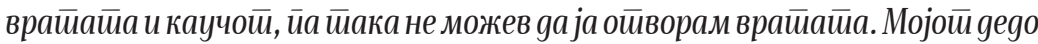
имаше 90 и кусур гооgини. Тайко ми го зеgе и го оgнесе наgвор. Мајка ми, 
сесйра ми и брай ми беа во сйалнайа. Некако не се йлашев. Сииее излег̄оа йо йижами освен јас шӣо бев облечен бияејќи се сиремав за рабойа.“

Госпоѓа Снежана, која за жал почина оваа година, била дете и ми кажуваше дека вечерта пред земјотресот тие слушале како викаат животните од Зоолошката градина. Биле вознемирени цела ноќ.

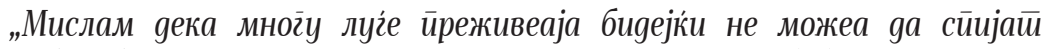
и беа буяни. Сё ушйе се сеќавам на йие звуци. (...) Живеевме во

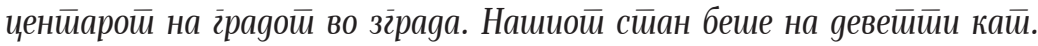

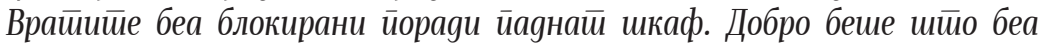

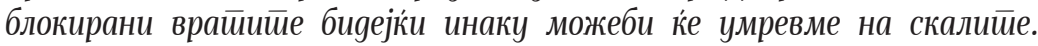

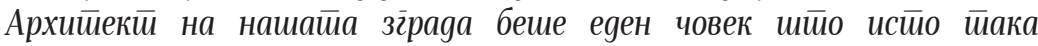

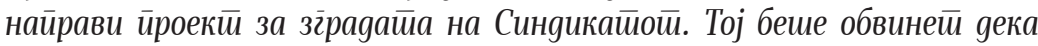

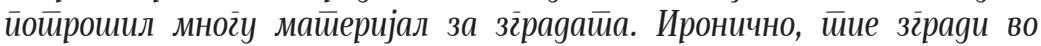

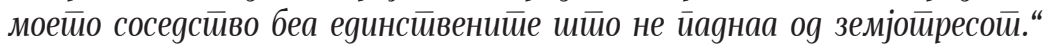

Еден маж што живеел во близина на железничката станица ми кажуваше дека во тој период имал многу гости дома. Тие биле:

„Оg Србија и Бугіарија, и се сеќавам gека куќа̄̄а беше ӣолна со луі́е. Јас

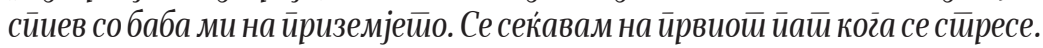

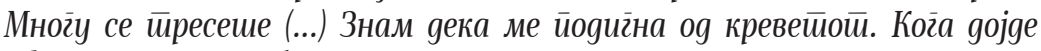

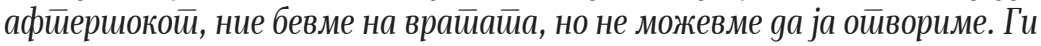

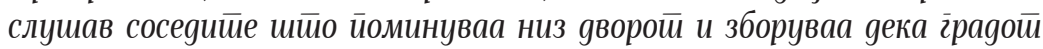
бил найаgнай со айомска бомба и дека се случува војна. Не знаевме gека

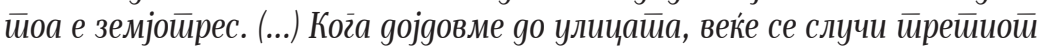

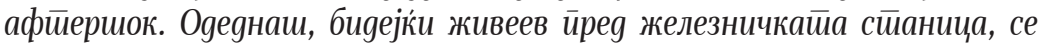
йојави голем облак шӣо йомина низ улицайа. Тоа беше облак оg йрав. (...) Најмног̈у се сеќавам на еgно момче шйо се качи на йокривой на еgен мерцеяес и викна 'луѓе, ajge gа се орїанизираме и gа йочнеме gа койаме ӣog

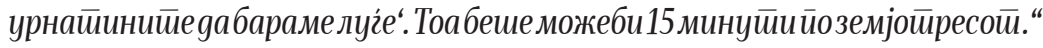

Госпоѓa Јелица, која за жал почина пред две години, се сеќаваше дека се преселиле во күќа во Хиподром кратко пред земјотресот:

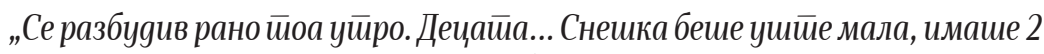

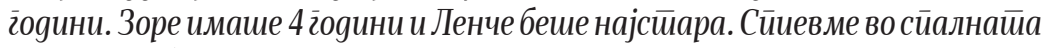
ког̈а се разбуgија ќеркийе. Му реков на маж ми gека е ушиее рано и дека ке йробам gа йосйијам ушие малку. Тој ирребаше gа сйане и gа се сйрема

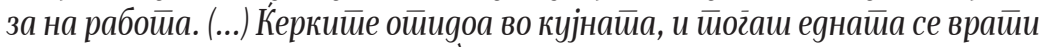
и ми рече gека сака gа јаgе леб. Й реков: 'Зошйо сакаш gа јаgеш леб? Рано

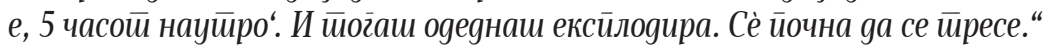

Следната приказна ја добив од еден човек што контактираше со мене откако напишав во фејсбук-групата „Стари скопјани“ дека барам луѓе што би сакале да 
зборуваат за земјотресот. Тој ми прати писмо од господин Драган. Бил дете во тој период и одел кон железничката станица бидејќи со семејството сакале да одат на одмор во Струга.

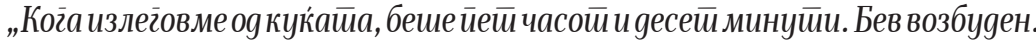

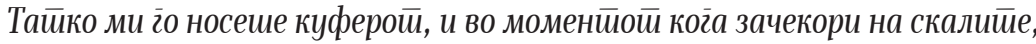

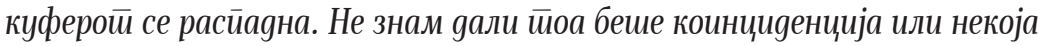

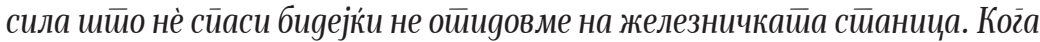

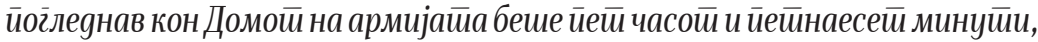

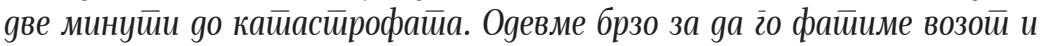

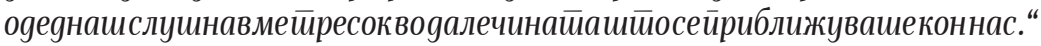

\section{За време на земјотресот}

За самиот земјотрес соговорниците зборуваа со емоции опишувајќи колку било тешко. Овој вид трауматични настани: „се случува кога ќе се појави ужасен настан и кога се активираат механизмите за опасност што на ниеден начин не можат да го спречат или да го ублажат настанот. Како резултат на тоа, сѐ што се случува во телото, а чија цел е да му помогне на човекот да избега, да даде отпор или да интервенира во хоророт не може да им служи на целите“ (Phillips 2017: 23). Многумина од соговорниците зборуваа за ужасните звуци за време на земјотресот.

Госпоѓа Снежана вели дека:

„Секој скойски земјойрес има сиеецифичен ужасен звук. Тоа е

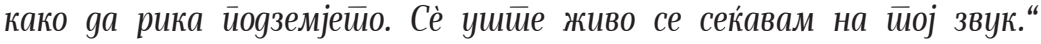

И сеќавањата на господин Драган се сѐ уште многу живи за случувањата за време на земјотресот.

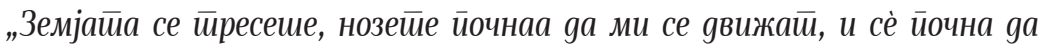
йаźа околу мене. Не знаев шйо се случува. Некои жени викаа: 'Синко,

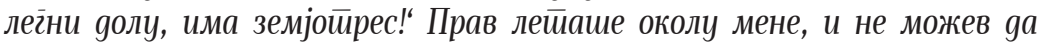

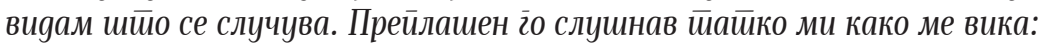

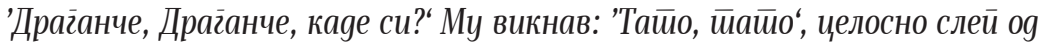

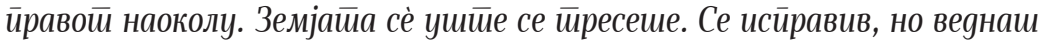
йаgнав. Не беше можно gа се сйои мирно. Одеgнаш йочна gа се смирува,

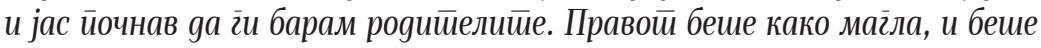

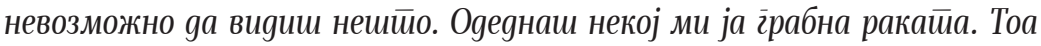

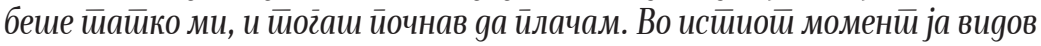
мајка ми. Бегавме заg собраниейо. Таму имаше еgна мала чуварница, и внайре имаше йолицаеи. Тој викаше: 'Бегіајие, ова е војна, Југославија е

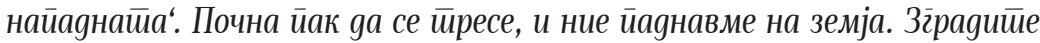

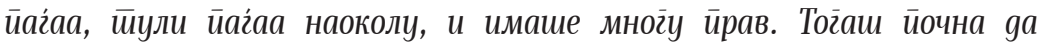
се смирува, и се исирравивме. И венеска гоо ирреживувам йој сиирав.“ 
Госпоѓa Милица се сеќава на моментот кога сѐ почнало да се тресе.

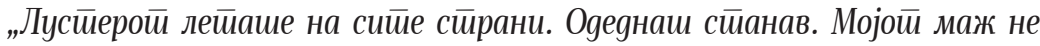

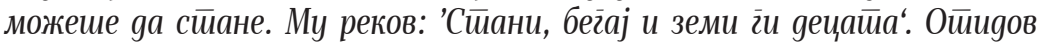

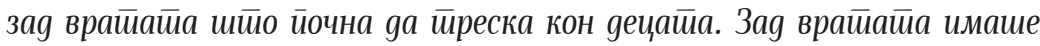

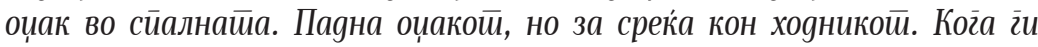

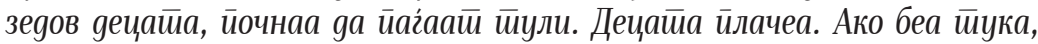

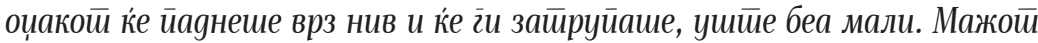

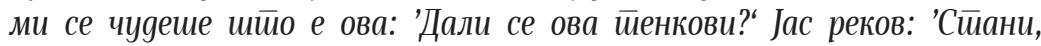

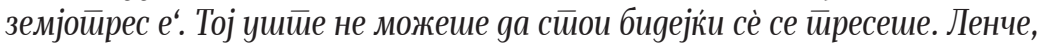

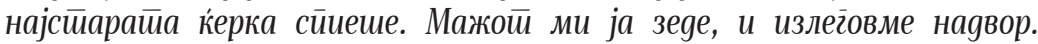
Глеgавме кај кукийе на сосеgишее, и сѐ беше во чаg. Јас реков: 'O боже,

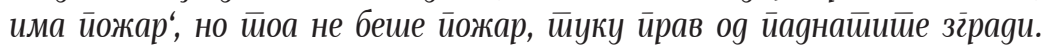
Еgна сосейка беше наgвор и йочна gа йрча кон куќйа за gа гоо викне синой. Тој беше војник и не беше gома йој gен. Женайа йаgна, се се йресеше. Пойоа йог̆леgнав кон gругіиие сосеgи. Ги сйасуваа децайа

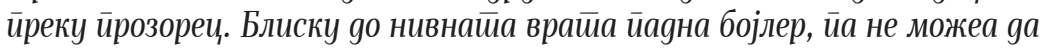

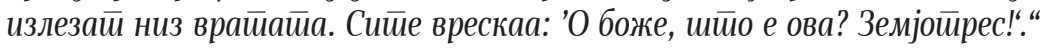

\section{По земјотресот}

Повеќето од соговорниците зборуваа дека луѓето во овој период биле солидарни меѓу себе, но исто така зборуваа и за солидарноста од целиот свет. Помош пристигнувала од целиот свет. Од друга страна, соговорниците зборуваа за тешките последици на оваа катастрофа.

Господин Сотир вели дека не се плашел за време на земјотресот, но кога одел кон центарот на градот за да им помага на другите, се исплашил кога ја видел реалноста.

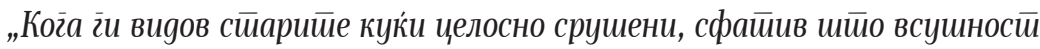

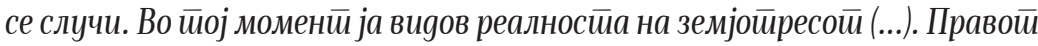

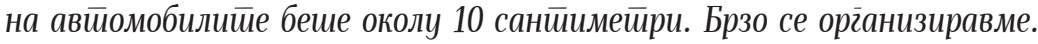

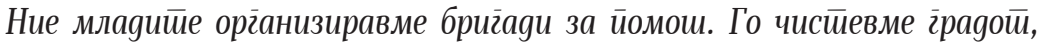

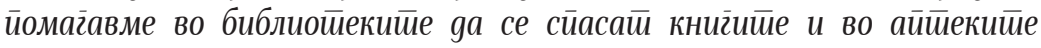

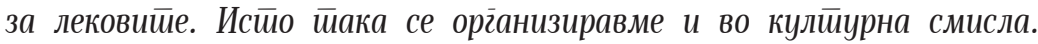
Организиравме насйани за gа се йочувсйвуваме како gа сме сѐ

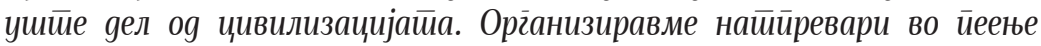

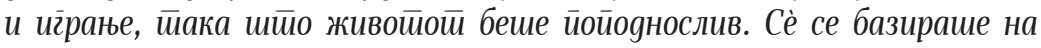

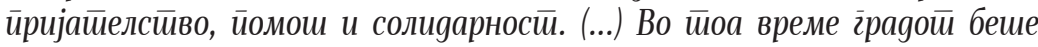
мал, не беше голем како шйо е gенеска. Речиси сийе се йознававме. 


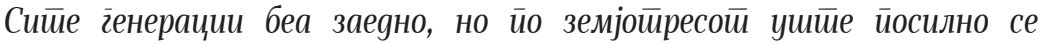
иоврзавме. Не беше сѐ йака црно. Игравме оро, имавме йрейсйави.“ земјотресот.

Господин Драган напиша дека не можел да ги заборави сцените по

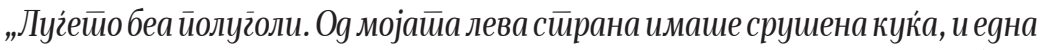

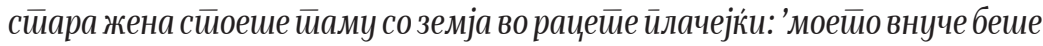

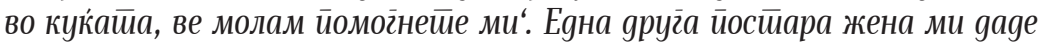

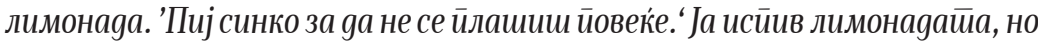

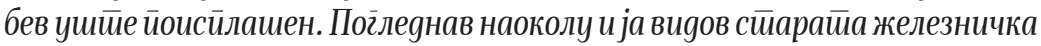

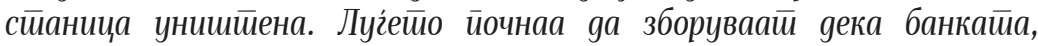

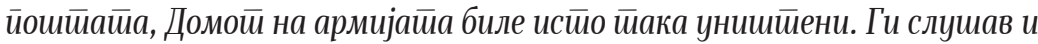
не можев gа верувам дека моейо Скойје исчезна за само неколку секунди.

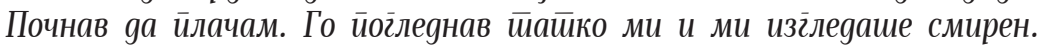

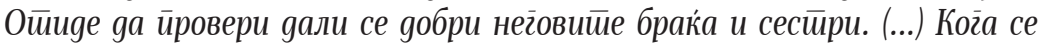

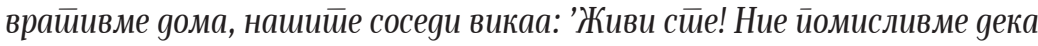
железничкайа сйаница се срушила врз вас:. Ако не се скршеше мојой

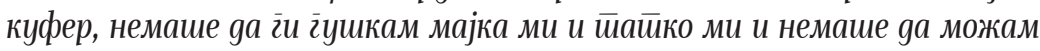

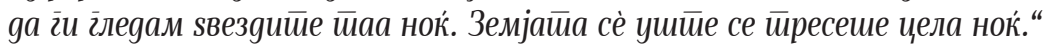
уништени.

Семејството на госпоѓа Јелица од Хиподром не знаело колку многу згради се

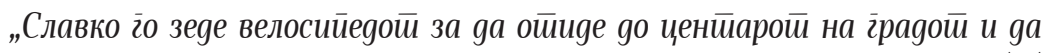

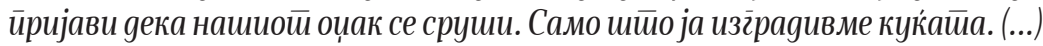

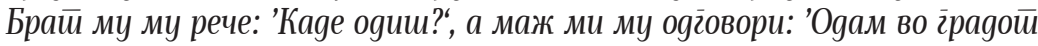

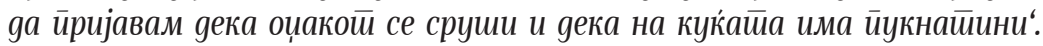

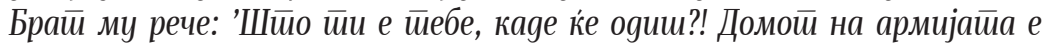
срушен, железничкайа сиианица, целиой граg е унишиеен. Сеgи gома:

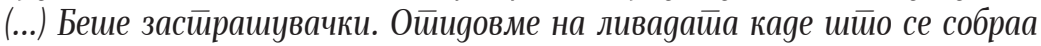

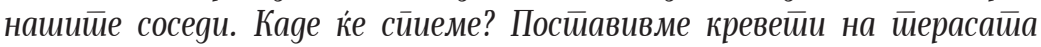

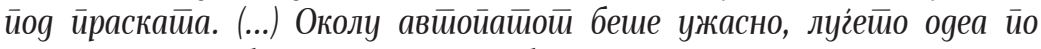
йижами, некои беа крвави, некои беа голи. Неколку gена йоgоцнна сѐ

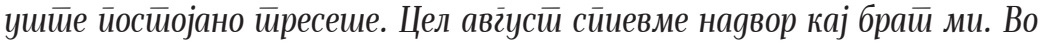

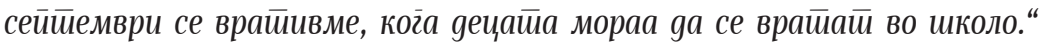

\section{Некои го опишуваат Скопје како воена зона:}

„Скойје изїлеgаше како gа е во војна. Беше иеемно на улицииее, имаше урнайини, беше како йусииина - никој немаше наоколу. Само иолицајциие се грижеа за мришвиой граg. Ова е Скойје денес - евройска Хирошима. Хирошима во мир. И gење беше ирразно. На балконииее овенале

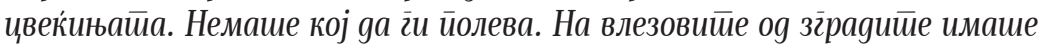
ливчиња харйија. На некои оg нив йишуваше: 'Мамо, јас сум жив. Јас сум во Тафйалиие, шайор број 12'. На gруїо ливче йишуваше: 'Перо, 


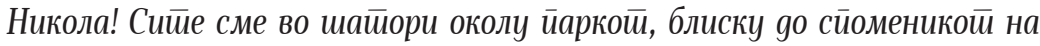
Гоце Делчев. Не влег̄увајӣе во куќа̄̄а““ (Наумовска и Шойов 2014: 53).

Госпоѓа Снежана се сеќава дека се појавиле стаорци насекаде по земјотресот.

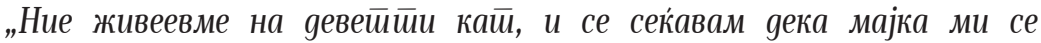

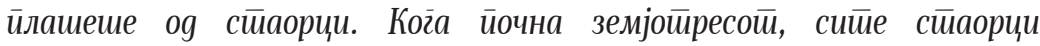

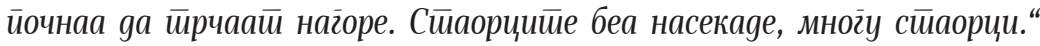

\section{Скопје денес}

По земјотресот започнала изградбата на Скопје. Вообичаено постои правило дека по земјотрес „зградите за брза помош, инфраструктурните објекти и станбените објекти се градат најбрзо. Здравствените, образовните и административните објекти се градат во некој среден временски период. За повеќенаменските и културните објекти е потребно подолго време за да се изградат“" (Al-Nammari, Lindell 2009: 472). „Најмал трошок има за станбените објекти, објектите за брза помош и инфраструктурните објекти. Некоја средна сума трошок е потребна за административните, културните, образовните и здравствените објекти. Најголем трошок подразбираат повеќенаменските објекти“ (Al-Nammari, Lindell 2009: 472). За повторна изградба на градот биле ангажирани многу архитекти од Југославија, но и од целиот свет. Зборовите на Тито: „Скопје доживеа невидена катастрофа, но Скопје повторно ќе го изградиме со помошта на целата наша заедница, тоа ќе стане гордост и симбол на братството и единството на јүгословенската и светската солидарност“ официјално го „започнаа реконструктивниот процес“ (Tolic 2019: 40). Овие зборови може да ги видиме и денеска „на старата скопска железничка станица, зградата што стана симбол на уништувањето и која денеска е претворена во музеј на градот“" (Tolic 2019: 40).

На старата железничка станица во Скопје стои часовникот што „застанал точно на 5:17 часот на 26 јули 1963 година“"(Kritikos 2019: 11). Ваквото замрзнато време честопати служи за обележување на катастрофите (Kritikos 2019: 11). Критикос вели дека „дури и овој расипан часовник е точен двапати во денот, и тој добива подлабоко значење; на секои дванаесет часа потсетува за моментот кога часовникот престанал да работи, и овој момент е реален исто колку што се реални другите моменти од одреден ден“ (Kritikos 2019: 11-13). Од друга страна покажува дека „часовникот е оставен така, спротивставувајќ ја состојбата во која тој се наоѓa со остатокот од градот што продолжил да живее“ (Kritikos 2019: 12-13). Часовникот е исто така потсетник за „манифестацијата на меѓународната солидарност, еден момент од историјата што е важен не само за граѓаните на Скопје туку и за светот“ (Kritikos 2019: 12-13).

На ова место сакам да ги подвлечам зборовите на повеќето од моите соговорници: „Да не се повтори никогаш“. 


\section{ЕтноАнтропоЗум}

\section{Литература}

Јаневски, Славко ур. 1970. Скойје. Београд: Младост.

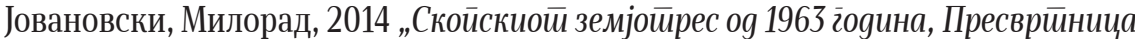

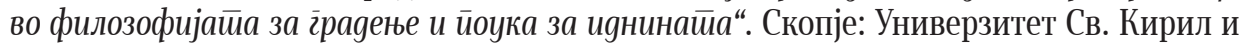
Методиј, Градежен факултет Скопје.

Наумовска, Сенка и Иван Шопов, 2014 „50 голини оg земјойресой во Скойје: Скойје - анйичко или моgерно. Скопје: Темплум.

Al-Nammari, Fatima, Lindell, Michael K. 2009. „Earthquake recovery of historic buildings: Exploring costs and time needs“. Disasters 33 (3), 457-481. (4), 331-347.

Bendix, Regina 1990. „Reflections on Earthquake Narratives“. Western Folklore 49

Kritikos, Christos-Georgios 2019. „The days after: Skopje's first steps towards reconstruction“. The Future as a Project. Hellenic Institute of Architecture.

Petrovski, T. Jakim 2004. „Damaging Effects of July 26, 1963“. MESF Cyber Journal of Geoscience (2).

Phillips, Elizabeth 2017. „Narrating Catastrophe, Cultivating Hope: Apocalyptic Practices and Theological Virtue“. Studies in Christian Ethics 31 (1), 17-33.

Sinadinovski, C., McCue, K. F. 2013. „50 years since the Skopje 1963 Earthquake: Implications for Australian building standards“. Australian Earthquake Engineering Society 2013 Conference. Hobart Tasmania.

Stein, F. Howard 2002. „Toward an Applied Anthropology of Disaster: Learning from Disasters - Experience, Method and Theory“. Illness Crisis \& Loss 10 (2), 154-163.

Timovska, Maja 2011. „Using knowledge to save lives in case of earthquake“. Technology, informatics and education for learning and knowledge society. 6th International Symposium. Technical Faculty Čačak.

Titon, Jeff Todd 1980. „The Life Story“. The Journal of American Folklore 93 (369), 276-292.

Tolic, Ines 2019. „The Protagonists of Skopje’s Reconstruction“. The Future as a Project. Hellenic Institute of Architecture. 